\title{
Hierbas medicinales y semiosis colonial: llustraciones indígenas en dos manuscritos novohispanos sobre la naturaleza americana del siglo XVI
}

Palabras clave

semiosis colonial saberes médicos hierbas medicinales representación
Julio Vera Castañeda"

Fecha de recepción: 19 de octubre de 2018. Fecha de aceptación: 30 de enero de 2019

\section{Resumen}

El presente artículo propone una relectura del herbario elaborado por el "médico" Martín De la Cruz, traducido al latín por Juan Badiano en 1552, y "el tratado médico" que forma parte del Códice Florentino de Bernandino de Sahagún (1577), a partir de la noción de semiosis colonial. La calidad mixta de estos artefactos -estar conformada por imágenes y textos- y la participación directa de los sabios náhuatl, habilita considerar las representaciones visuales de las hierbas medicinales como enunciados portadores de cierta autonomía, pese a estar inscritos dentro de los géneros de representación europea. Esta particularidad pone en tensión la supuesta subordinación de los significantes visuales al imperativo de la escritura alfabética, dando cabida a valorar la presencia de representaciones heterogéneas en el contexto de la alfabetización mesoamericana en el siglo XVI.

Medical herbs and colonial semiosis: Indigenous illustrations within two Novo-Hispanic manuscripts on American nature of the 16th century

\section{Abstract}

Key words

colonial semiosis materia medica medicinal herbs representation
This article proposes a new read of the herbal put together by "Doctor" Martín de la Cruz, translated into Latin in 1552 by Juan Badiano, and the "medical treaty" which is part of Bernardino de Sahagún's Florentine Codex (1577) based on the notion of colonial semiosis. The combination of images and texts in these artifacts and the direct participation of wisemen of Náhutl origin allow the consideration of visual representations of medicinal herbs as statements that retain certain autonomy, despite being included within the genres of European representation. This peculiarity strains the alleged subordination of visual

* Licenciado en Historia y candidato a Magíster en Estudios Latinoamericanos, Centro de Estudios Culturales Latinoamericanos (CECLA), Universidad de Chile, Chile. Becario Comisión Nacional de Investigación Científica y Tecnológica (CONICyT). Santiago de Chile, Chile. E-mail: julio.vera@um.uchile.cl. 
signifiers to the imperative of alphabetical writing, making it possible to assess the presence of heterogeneous representations within the context of Mesoamerican literacy in the sixteenth century.

\section{Introducción}

En 1552, el "médico" Martín De la Cruz y Juan Badiano, dos indios adscritos al Colegio de Santa Cruz de Tlatelolco, dan por finalizado un herbario sobre la materia médica de Nueva España al que titularon Libellus de medicinalibus indorum herbis (Figura 1). Se los había solicitado Francisco de Mendoza, hijo del virrey Antonio de Mendoza, para enviárselo como obsequio al recién abdicado Carlos V y solicitar la renovación del financiamiento del colegio. Como es sabido, no eran buenos años para la iniciativa franciscana: dos de sus defensores políticos se habían marchado -el arzobispo Juan de Zumárraga había muerto en 1548 y el virrey Mendoza había partido al Perú- mientras que, de manera paralela, se acrecentaba el debate en torno a la naturaleza de los indios, su inferioridad moral y la utilidad o inutilidad de su educación dentro del programa de la cristianización. Es dentro de ese contexto que cobra sentido leer la dedicatoria que firma Martin de la Cruz:

Pues no creo que haya otra causa de que con tal instancia pidas este opúsculo acerca de las hierbas y medicinales de los indios, que la de recomendar ante la Sacra Cesárea Católica y Real Majestad a los indios, aun no siendo de ello merecedores. Ten presente, señor, que nosotros los indios, pobrecillos y miserables somos inferiores a todos los mortales y por esta nuestra pequeñez e insignificante natural, merece indulgencia (De la Cruz, [1552] 1996: f. 1v).

En la lógica de la escritura como servicio y respuesta a un mandato, el herbario constituía un instrumento político en donde los indios reclamaban su humanidad y, desde un pilar de inferioridad, "que podían ser educados, y que poseían una cultura meritoria" (Ortiz de Montellano, 1993: 35). Mendoza buscaba reivindicar la condición de buenos vasallos y cristianos y, de paso,

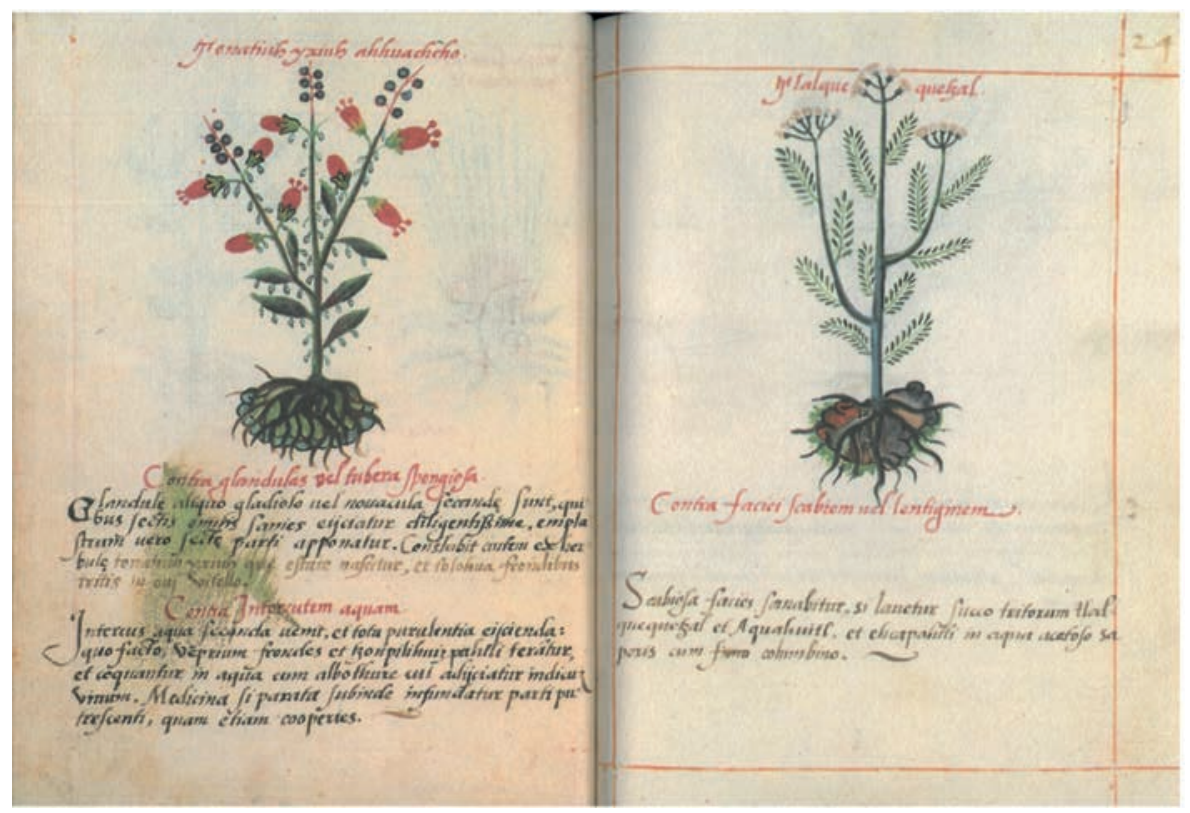

Figura 1. Libellus de medicinalibus indorum herbis, fs. 23v. y 24r. (Del Pozo, 1996). 
1. Francisco Mendoza logró enviar o presumiblemente llevar el manuscrito a España durante el corto reinado de la infanta doña Juana (1554-1559), quedando el herbario inmerso en la Biblioteca de El Escorial sin que se le hiciera mención alguna en varios años (Viesca Triviño, 1995: 71-72). Varios decenios después aparece entre las manos del boticario real de Felipe IV, quien posiblemente lo trasladó a Italia donde otro boticario realizó una copia. Por razones desconocidas, el herbario terminó en manos de un cardenal italiano, Francesco Barbeni, posiblemente debido a su estancia entre 1625 y 1626 como legado de la Santa Sede en España, para finalmente permanecer en su biblioteca hasta 1902 cuando pasó a ser parte de la biblioteca del vaticano bajo la signatura Codex Barberini, Latin 241 (Rey Bueno, 2004: 256-257; Afandor Llanch, 2011: 14).

2. Según nos cuenta en el prólogo del segundo libro, Sahagún organizó la información que les proporcionaron durante años los sabios indígenas, gracias a un cuestionario que ensayó por vez primera en Tepepulco entre 1558 y 1559, donde obtuvo un documento en náhuatl al que llamó Primeros memoriales y que usó después para el desarrollo de un cuestionario más extenso. Una segunda etapa de esta obra se desarrolló en Tlatelolco, editando el manuscrito y elaborando lo que hoy se conoce como Códice Matritense, también escrito en náhuatl. Una última etapa de recopilación se da cuando Sahagún se trasladó al convento de San Francisco de la ciudad de México en 1565, donde la obra volvió a revisarse hasta convertirse en el mencionado Códice Florentino.

3. Tomo la expresión propuesta por José Luis Martínez (1981) para referirme como conjunto al vocabulario en náhuatl de vocablos relacionados con el cuerpo humano que constituye el capítulo XXVII del libro $X$, titulado "De todos los exteriores e interiores así en el hombre como en la mujer", el segmento del capítulo XXVIII "De las enfermedades del cuerpo humano y las medicinas contra ellas" y el inventario de hierbas medicinales que forma parte del libro XI del Códice Florentino. vehiculizaba sus intereses económicos para explotar las riquezas vegetales americanas (Zetina et al., 2011: 223). Sin embargo, el destino del herbario, como el de muchos otros artefactos americanos enviados a la Corona, no cumplió con las expectativas de su origen. Después de una extensa trayectoria de circulaciones terminó en la biblioteca vaticana en 1902, ${ }^{1}$ para luego ser devuelto a México por el papa Juan Pablo II en 1990.

Más de veinte años después de haber sido enviado el herbario, tras una serie de presiones y censuras, el fraile Bernardino de Sahagún, con la ayuda de "escribanos" proporcionados por fray Rodrigo Sequera, reordenó, tradujo e ilustró el material sobre "las cosas de la Nueva España" con el que venía trabajando desde $1558 .{ }^{2}$ Un gesto excepcional, dado que el conocimiento de las costumbres y las tradiciones náhuatl con el objetivo de preservarlas (Todorov, 1987) ya no era visto con buenos ojos y se corría el riesgo de fomentar la idolatría de los indios americanos. Pese a esto, después de una extensa composición, el resultado de esa labor se tradujo en un enorme manuscrito que recoge el último estado de la documentación náhuatl, las ilustraciones y la traducción al español conocida como la Historia general de las cosas de Nueva España, manuscritos también conocidos como Códice Florentino. Bajo el modelo de la historia natural de Plinio y las enciclopedias medievales, Sahagún incluyó un completo "tratado de medicina indígena", ${ }^{3}$ dentro del que destaca un inventario de las hierbas medicinales del territorio (Figura 2), cuyos informantes son los únicos reconocidos expresamente por su nombre: Gaspar Mattías, Francisco Symon, Felipe Hernández, Miguel García, Pedro de Santiago, Miguel Damian, Pedro de Raguena y Miguel Motolinia.

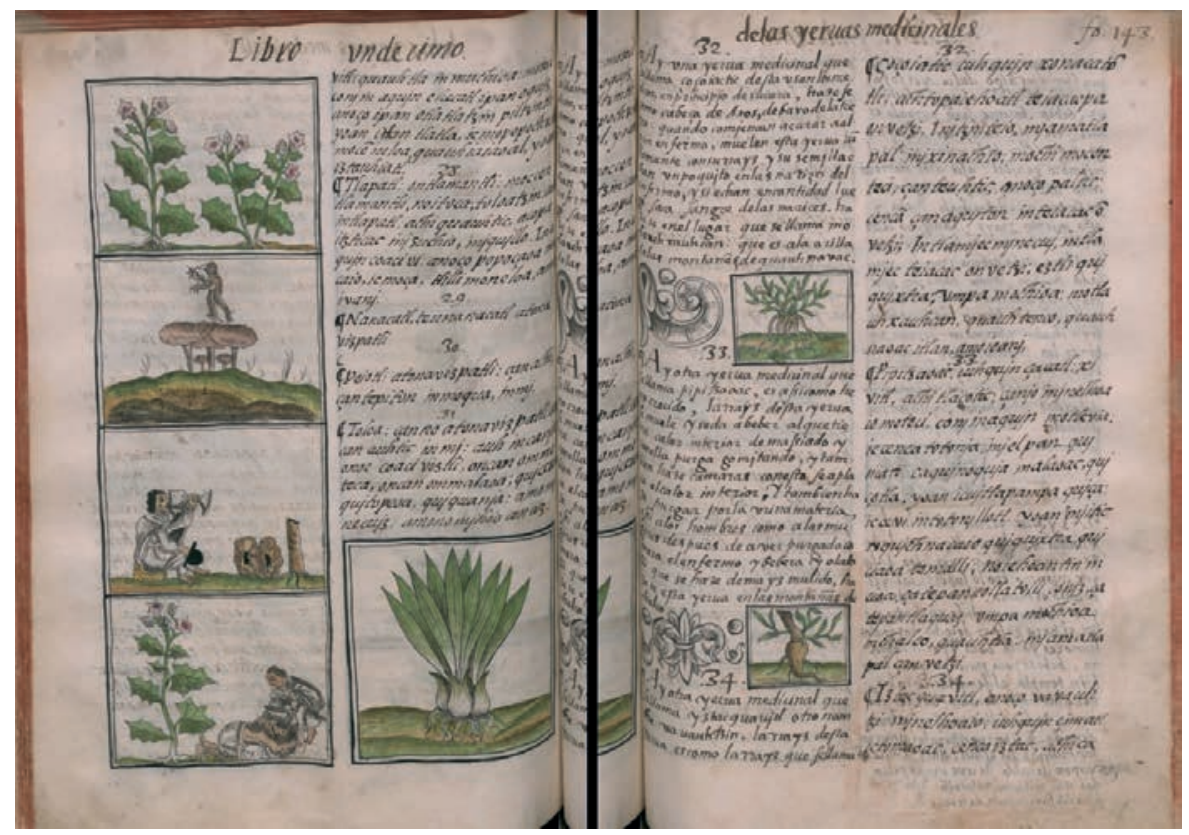

Figura 2. Historia general de las cosas de Nueva España, Libro XI, fs. 142v. y 143r. (Sahagún, 1577).

Estos manuscritos poseen más de un paralelo. Por una parte, constituyen valiosas fuentes para el estudio de la cultura médica novohispana temprana (PardoTomás, 2016) y un punto de entrada al mundo medicinal de los nahuas antes de la conquista (Ortiz de Montellano, 1993 y López Austin, 2012). Son, por la otra, manifestaciones del saber sobre y desde el territorio americano, que permiten el ingreso de lo desconocido a los márgenes del saber de la cristiandad 
occidental. Pese a su independencia, ${ }^{4}$ los textos comparten la impronta de las labores del Colegio de Santa Cruz de Tlatelolco, ${ }^{5}$ fundado por los franciscanos en 1536 cuyo objetivo era hacer de la elite indígena novohispana buenos cristianos y agentes de la colonización en calidad de mediadores (Laird, 2014: 152). Ambos textos acogen el criterio humanista que desplegaron los frailes y la preocupación por las constantes epidemias que azotaron a la población y la necesidad de enfrentarlas, manifestado en el registro de las prácticas curativas desplegadas por los tiçitl -término nahuatl aplicado a los sanadores expertos, en general- y el repertorio de hierbas que conformaban su arsenal médico.

En ese sentido, tanto el Herbario De la Cruz-Badiano como el "tratado médico indígena" del Códice Florentino se inscriben en la tradición de textos que describen plantas: los herbarios de tradición medieval y el género de la historia natural. La secuencia de lecturas y comentarios desplegados por la cristiandad occidental sobre el repertorio de obras de raíz clásica, pasado por manos árabes y conocimientos locales del más variado tipo, fijó como autoridades los modelos de escritura de Dioscórides y Plinio el viejo. Una tipología textual que describía las hierbas como expresión de la catalogación del orbe, buscando exponer sus virtudes curativas y, eventualmente, acompañarlas con ilustraciones y glifos con connotaciones mágicas (Turner, 2007). A esto hay que sumar la exigencia de confeccionar obras que fueran entendibles ante los ojos del rey. En ese sentido, los manuscritos se inscriben también en la tradición de libros ilustrados -bestiarios, colecciones de relatos de viajes, obras de saber geográfico, libros de trajes, entre otros-, que dan cuenta de la epistemología visual del siglo XVI, donde la imagen opera como evidencia y lenguaje legítimo para comunicar la naturaleza del Nuevo Mundo, ${ }^{6}$ tanto a nivel local como parte del proyecto Imperial de gobernar a distancia (Bleichmar, 2015).

Describir y poner ante los ojos del rey las "cosas de las Indias", mediante textos e ilustraciones, podía cumplir numerosas funciones tal como nos expresa el Libellus y los propósitos evangelizadores de Sahagún, quien vehiculizaba la traducción del saber indígena con el fin de conocer, tal como un médico, "de que humor o de que causa procede La Enfermedad" (Sahagún, 1577, Libro 1, f.1). Sin embargo, los manuscritos invocan y dialogan, igualmente, con la tradición mesoamericana donde las figuras de hierbas o plantas tienen lugar (Afanador Llanch, 2011; Magaloni, 2014; Reyez Equiguas, 2016). En ese sentido, ¿cómo leer su vinculación con la escritura pictoideográfica y la producción de códices con contenidos diversos que existían antes de la invasión hispana? La adecuación del saber medicinal indígena dentro de estos manuscritos obliga a establecer la pregunta por los posibles lugares de enunciación de los indios cristianizados que participan, por medio de la pintura, la copia y la traducción, en la invención occidental de la naturaleza americana (O' Gorman, 2004) por medio de códigos y géneros de representación ajenos a su tradición.

\section{La semiosis colonial}

Ha sido una constante evaluar qué tan puros o contaminados son los textos coloniales que poseen la marca de los artífices indígenas tras la instalación del dominio colonial, principalmente por los efectos de la alfabetización y el correlato epistemológico de la marca escritural (Rama, 2004). A pesar de ello, conviene preguntarse: ¿hasta qué punto los géneros de representación occidentales determinan el contenido de las ilustraciones expuestas en estos manuscritos?; o, yendo más lejos, ¿qué nos dice la dimensión comunicativa de estos artefactos culturales en una sociedad marcada por la experiencia
4. Como se ha podido detectar, al parecer Sahagún nunca tuvo noticias del herbario ni mucho menos del médico Martín de la Cruz quien, se intuye, entró a las inmediaciones del colegio con el propósito de ejercer como médico. Otras interpretaciones sugieren que Sahagún no incluyó a Martín de la Cruz dentro de sus informantes médicos porque estaba "excesivamente influido por la medicina europea” (Del Pozo, 1996: 333) y no le resultaba útil a sus propósitos.

5. Junto a la alfabetización del náhuatl, los jóvenes indígenas aprendían a leer y escribir en castellano y en latín, familiarizándose con el repertorio de autoridades del saber occidental, como es el caso de Plinio, Tito Livio, Cicerón, los Padres de la Iglesia, Nebrija, Erasmo, entre otros, y las artes de la gramática, la retórica, la lógica, la traducción, la copistería, pero también con el dibujo y el canto. La eficacia de esta política permitió que durante unos veinte años -de 1546 a 1565 - los mismos estudiantes indígenas llegaran a tener bajo su cargo una parte de la enseñanza que se impartía a los nuevos alumnos (Afanador Llanch, 2011: 18; Gruzinski, 2013: 65).

6. Con este mismo propósito se habían confeccionado obras ilustradas como el Sumario de la historia natural de Fernández de Oviedo, impresa en Toledo en 1526 , quien consideró necesario hacer dibujos puesto que algunos aspectos de la naturaleza americana le resultaron difíciles de describir (Bleichmar, 2015: 252). 
7. Del latín arte factum, "hecho con arte", la palabra refiere a un objeto, especialmente una máquina o un aparato construido con una cierta técnica y con un determinado fin (Real Academia Española, 2014). colonial? Si reconocemos que la conquista europea en América instaló, desde el desencuentro entre los lenguajes, el problema del habla y el decir entre horizontes de comprensión forzados a explicarse y apropiarse, la comunicación se torna un problema de gran envergadura.

Eliseo Verón (1993) teorizó sobre la semiosis social. Desde el campo de la semiología, propuso un modelo de interpretación que pudiera dar cuenta del funcionamiento de los discursos en la sociedad: la generación, recepción, circulación y, a largo plazo, su impacto en la construcción social de lo real. Definió la semiosis social como "el estudio de los fenómenos sociales en tanto procesos de producción de sentido [...] [aunque] ello no quiere decir, sin embargo, que manifiesta las mismas modalidades en todos lados, ni que la sociedad en su conjunto tengan algún tipo de unidad significante" (Verón, 1993: 125). Desplazando la primacía del signo y relevando la pregunta por los significantes, Verón invitó a pensar las formas en que los sujetos interpretan y dan sentido a lo social desde la producción de anunciados diversos e inscritos en materialidades heterogéneas. Considero que esta propuesta habilita evaluar las maneras en que los diferentes actores coloniales otorgan y dan sentido a su realidad, reconociendo la multiplicidad de sentidos posibles, incluso discordantes.

En sintonía con estos postulados puede leerse la propuesta de Mignolo (1992, 1994) sobre la noción semiosis colonial para el estudio de las producciones discursivas amerindias, acentuando la interacción entre distintos sistemas de signos en contextos coloniales. Rescato de esta propuesta la atención que puede prestarse a otras formas de registrar y comunicar: el complejo mundo de la oralidad y manifestaciones escrituras como la ya mencionada escritura pictoideográfica mesoamericana (León Portilla, 2003; Gruzinski, 2013) y el complejo sistema de los quipus andinos (Cummins, 2004), reevaluando las categorías eurocéntricas con las que catalogamos los medios de expresión, las relaciones de poder que caracterizan la construcción de relaciones coloniales y el rol que en ella juega el despliegue de la escritura alfabética.

En ese sentido, para la lectura de estos manuscritos creo útil la noción de artefacto, $^{7}$ retomando el énfasis propuesto por Verón (1993) sobre el soporte material que participa en la producción de sentido, ya que el artefacto no es un simple soporte o una elaboración técnica sino un objeto complejo en el que se traducen ideas, convenciones, prácticas y maneras de decir el mundo; para este caso, la tradición occidental de nombrar, clasificar y jerarquizar la naturaleza medicinal, en un ejercicio complejo de traducción de saberes y formatos.

\section{Reacomodos de los códigos mesoamericanos}

En vista de lo anterior, resulta ineludible comprender los manuscritos en sintonía con las transformaciones que experimentó la escritura pictoideográfica mesoamericana y sus soportes materiales tras la invasión hispana y el despliegue de las dinámicas coloniales. Como lo han hecho notar diversos estudios, la similitud entre los "códices" prehispanos y los soportes de escritura de aquellos pueblos que los europeos catalogaban de "bárbaros", permitió el diálogo entre estos sistemas e hizo más fácil la estrategia de evangelización a través de la alfabetización del náhuatl por medio de la confección de vocabularios y gramáticas (Mignolo, 1994; Gruzinski, 2013). Sin embargo, la tendencia a dar por sentada la primacía de las lógicas occidentales ha dejado de lado la plasticidad histórica de estos materiales y su capacidad de adaptación y cambio en distintos periodos y ante diversas coyunturas. Existen ejemplos tempranos 
que dan cuenta de esta versatilidad. Una de ellas la expresa el relato sobre "la merced y mejora de Hernán Cortés a los caciques de Axapusco y Tepeyahalco" en las cartas de relación:

En dos días del mes de abril de dicho año, a las once de la noche llegaron los dichos Tlamapanatzin y Atonaletzin con muchos indios de los suyos cargados de presentes y bastimentos y las pinturas en unos lienzos que acostumbraban, que se llaman nequene, y libros del papel maguey que se usa entre ellos; todo se manda por pinturas, estatuas (sic) y figuras imperfectas, y todo género de la tierra, árboles, cerros e ríos, calles y todo, sin faltar cosa, en ellas, pintadas y figuradas y con ellos un buen escribano de los que entienden y estudian para sus efectos; y traían unas varitas delgadas y sutiles con que iban señalando y llamando por sus tenores y órdenes: de lo cual yo, el dicho Hernán Cortés, y lo que en mi compañía estaban, quedamos admirados de la grandeza que veíamos y modo de gobierno, y ordenanzas... (Cortés, [1526] 1993: 65).

A esta impresión sobre los elementos que los conquistadores identificaron como "tierra, árboles, cerros e ríos", se suma el hecho de que los indígenas hayan expuesto su sistema como un medio de comunicación, más allá de que el relato no dé cuenta del "valor simbólico de cada significante" (León Portilla, 2012). Otro ejemplo lo expone fray Toribio de Benavente cuando los indios, según su relato, comenzaron a confesarse "por sus figuras y caracteres":

estando yo en Cholola, que es un gran pueblo cerca de la Ciudad de los Ángeles, eran tantos los que venían a confesarse, que yo no podía dellas recado como yo quisiera y díjeles: "Yo no tengo de confesar sino a los que trujeren sus pecados escritos y por figuras", que esto es cosa qe ellos saben hacer y entender, porque ésta era su escritura. Y no lo dije a sordos, porque luego comenzaron tantos a traer sus pecados escritos, que tampoco me podía valer, y ellos con una paja apuntando y con otra ayudándoles, se confesaban muy brevemente. $\mathrm{Y}$ de esta manera hubo lugar de confesar a muchos, porque ellos lo traían bien señalado con caracteres y figuras, que poco más era menester preguntalles de lo que ellos allí traían escrito y figurado (Fray Toribio de Benavente “Motolinía", [1858] 2014: 130)

Este pasaje sobre lo acontecido en 1537 bien puede leerse como un efecto de las estrategias evangelizadoras de los franciscanos sobre el sistema pictoideográfico mesoamericano, pero, al mismo tiempo, expresa la versatilidad de los sistemas mesoamericanos en contextos de paulatino entendimiento. Con esto quiero llamar la atención sobre la intención de estabilidad que tienden a expresar los textos coloniales y los efectos de verdad (Foucault, 1987, 2008) que suelen ser reproducidos en las interpretaciones históricas. No hay que perder de vista que el siglo XVI fue escenario de una contienda a gran escala para definir el nuevo orden de las cosas: convencer a los indios de que lo eran, enseñarles que tenían un alma e incluso sociabilizar las ideas occidentales sobre la existencia de una "naturaleza" bajo el esquema naturalista que caracterizaba el modelo renacentista (Descola, 2001). Sobre este tipo de problemas, Lamana (2016) se atrevió a establecer que, aunque los textos busquen dar cuenta de un orden, "en ningún momento hubo una configuración única o estable de significados" (Lamana, 2016: 13), reconociendo la existencia de desencuentros, fisuras y nulos entendimientos.

Estas ideas son elocuentes a la hora de prestar atención a los significantes de la tradición mesoamericana presentes en los manuscritos, como son el glifo de piedra (tetl) en el Códice florentino, con sus perfiles coruscantes en 
distintas composiciones y colores (Figura 3), y el glifo de agua (atl) presente en el Herbario De la Cruz Badiano en la foja 9r, correspondiente a la hierba xihuamolli (Figura 4). Es interesante tomar nota del último caso, puesto que el glifo posee un valor fonético y no representativo del entorno natural -el término atl vale para referirse al fonema "a" de la hierba xihuamolli. Como señala Reyes Equiguas (2016), todos los esfuerzos de clasificación botánica y lingüística dan cuenta de que esta hierba no crece en medios acuáticos, lo que significa que el glifo toma "una función nemotécnica para reforzar por medio de una vocal la manera en que iniciaban las raíces nominales que participaban en los nombres de ciertas plantas" (Reyes Equiguas, 2016: 30-31). Al ejemplo señalado, hay que sumar otros casos donde efectivamente el glifo sirve como solución plástica para el entorno natural; otras formas de representar el agua, como los grados de manchas de color azul sin líneas de contorno de la foja 44r., y también los casos de hierbas que se vinculan con el medio acuático pero que no presentan ninguna de las representaciones mencionadas, como es el caso de la hierba achilli en la foja 37r.

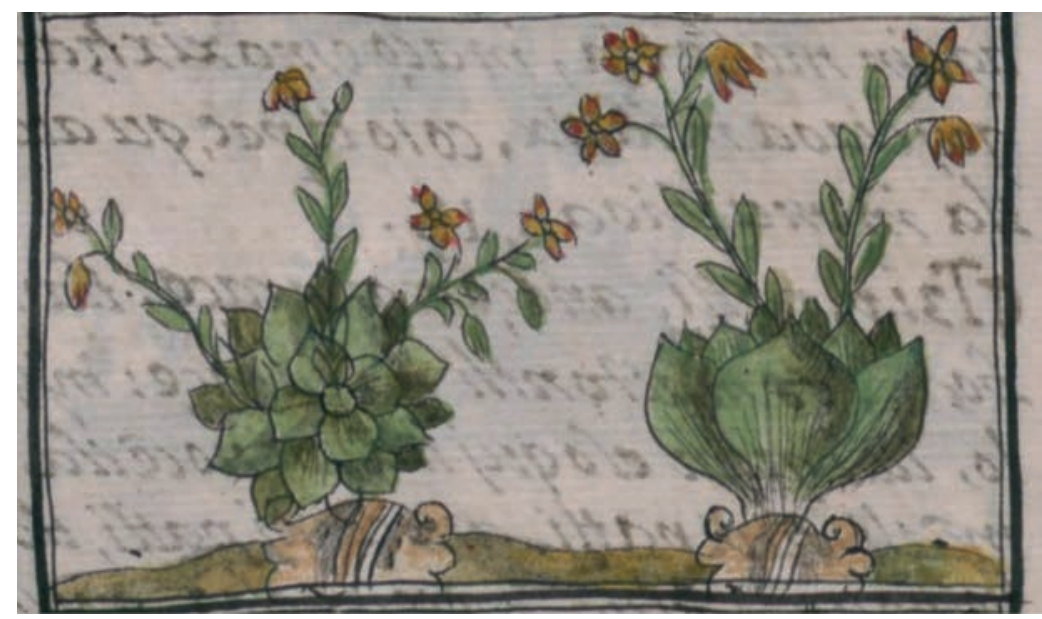

Figura 3. Historia general de las cosas de Nueva España, Libro XI, f. 141v. (Sahagún, 1577).

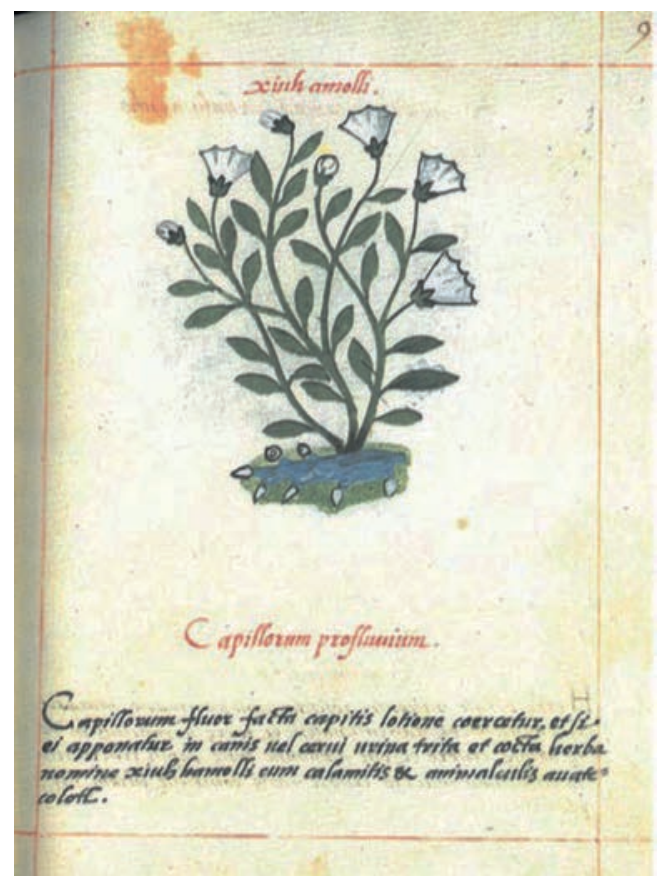


Por otra parte, es importante señalar el carácter "aumentando" de todas las raíces de las hierbas dentro de las ilustraciones del Códice Florentino, que pese a estar encuadradas dentro de un aparente paisaje que caracteriza el entorno de la hierba -montes, llanuras o simplemente un suelo vegetal-, este no las obliga a representarse como si salieran de la tierra sino de manera superpuesta (Figura 5). Al igual que la ausencia de significantes para denotar el entorno en el Libellus, en el Códice Florentino las hierbas medicinales se presentan en tensión del paisaje que busca representar su "medio natural". Estas son características presentes en otros manuscritos del siglo XVI, como las plantas en el Códice Xitotepec, que expresan también el carácter de las raíces fuera de la tierra (folios 11 y 13) y el glifo de agua junto a una de ellas (folio 13). Para StresserPéan (1995), la forma en que están representadas estas plantas sigue el patrón prehispano y cumple objetivos referenciales dentro del carácter histórico del manuscrito, pese a presentarse como partes del "paisaje". En el folio 13, la planta junto al glifo funciona como nombre de "lugar de frutos -con forma- de barcas" (Stresser-Péan, 1995: 107), pese a estar junto a una glosa en náhuatl que dice acalxocotlan, fruto o lugar completamente desconocido.

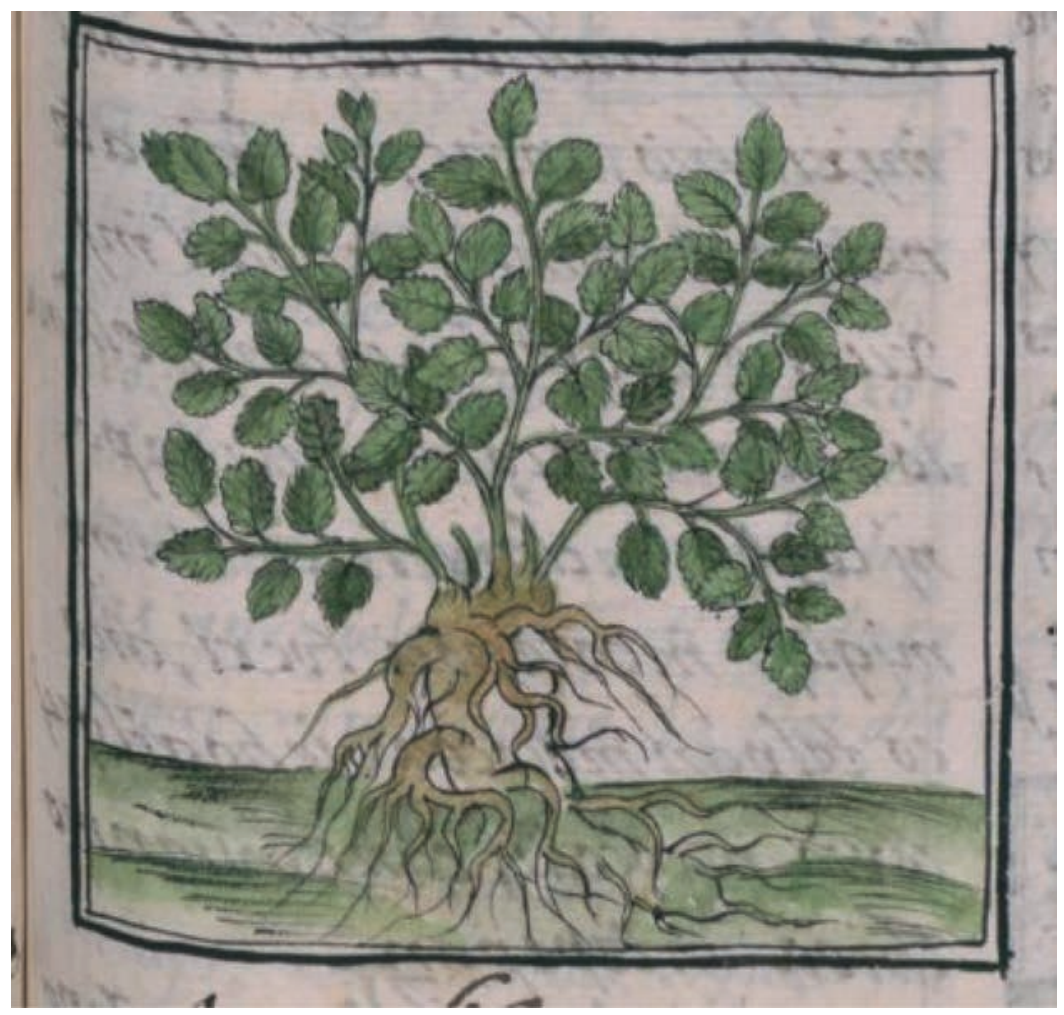

Figura 5. Historia general de las cosas de Nueva España, Libro XI, f. 152r. (Sahagún, 1577).

Estos ejemplos nos recuerdan la extensa tradición de usar representaciones de hierbas con distintos propósitos en la producción de códices mesoamericanos, y que su inscripción en artefactos de comunicación de raíz europea no clausura los modos de expresión mesoamericanos en calidad colonial. Por su parte, la opción por representar bajo criterios europeos no subordina, ni margina estas otras formas; por el contrario, conviven de manera paralela. Por consiguiente, no creo que la transformación de los lenguajes visuales responda única y exclusivamente al patrón de la alfabetización, tal como lo ha planteado el modelo de la hibridez o el mestizaje que Gruzinski (2013) empleó para leer las producciones de los tlacuilos durante el primer siglo colonial novohispano. Es una lectura que "mestiza" a sujetos indígenas, negando su condición política y su agencia 
8. Las imágenes sumaron a su utilidad representacional la condición de "evidencia", lo que permitió la permanencia del significado andino de las imágenes gracias al reacomodo de sus códigos dentro de las representaciones occidentales.
9. Ha sido una constante identificar la tradición de los herbarios medievales como el modelo visual y discursivo del Libellus; dejar la parte superior para la ilustración y la sección de abajo para el texto, la división de los espacios mediante subtítulos y la representación de las hierbas de un modo plano y simétrico. Todas estas características respondían a las maneras de describir las virtudes medicinales de las hierbas que comenzaron a ser estandarizadas gracias a los alcances de la imprenta y el uso de la categoría "herbario", inexistente hasta el siglo XV, para referir a un tipo de texto heredero de una tradición más amplia y heterogénea (Anderson, 1997: 1-2). En particular, los herbarios seguían el modelo textual de la obra de Dioscórides, De materia médica, ya que a diferencia de sus predecesores, como Teofastro, presentaba una visión fundamentalmente práctica de la naturaleza (Anderson, 1997: 14), junto a la identificación de la planta se primaba las maneras de extraer sus virtudes curativas y no ahondar en la descripción detallada de la hierba. En ese sentido, los llamados herbarios medievales destacan por la importancia que poseían las descripciones textuales, en contraste al rol atribuido a las imágenes que ilustraban los textos (Elliott, 2011: 27) pues, paradójicamente, las imágenes resultaban útiles para quienes ya conocían la planta y no necesitaban la ilustración como guía en el campo. en contextos de dominación, además de asociar aculturación con el sinnúmero de soluciones plásticas que incorporan elementos cristiano-occidentales.

Hay otros estudios que han dado cuenta de que esta incorporación es una práctica extensiva a todo tipo de registros, como el estudio de Thomas Cummins (2004) sobre los queros coloniales, cuya transformación "no significaron la pérdida de significados andinos" (Cummins, 2004: 230), sino un cambio en los modos en que eran enunciados. ${ }^{8}$ Algo similar ocurre con el arte rupestre, un sistema de registro y comunicación más amplio y complejo que siguió operando a expensas de los modelos europeos pero que, de todas formas, incorporó nuevos contenidos y significantes de procedencia hispana (Martínez, 2009). Que los manuscritos respondan al espacio formativo del Colegio de Tlatelolco tampoco es sinónimo de una absoluta imposición sino, por el contrario, es un escenario de la ósmosis teniendo en cuenta que los frailes adoptaron parte del modo de vida indígena, principalmente la alimentación, y que los alumnos sirvieron como "profesores o animadores a los monjes deseosos de "nahuatlizarse" y de empaparse en el saber prehispánico, pero por una alquimia que no es la del mestizaje sino más bien la de la doble pertenencia cultural" (Duverger, 1996: 180).

\section{Escribir y pintar las hierbas medicinales}

Paradójicamente, esta separación que habilita la construcción de jerarquías de voces en la producción de saber escrito es la que permite la participación de los indígenas, ya sea en calidad de informantes, traductores o pintores de los dibujos sobre las hierbas medicinales. Conviene detenerse en el Libellus, pues establece un lugar de enunciación y un referente, un modo de decirle al rey quién habla y desde dónde lo hace. Hablan los indios: el "indio médico" Juan de la Cruz y "por raza indio" Juan Badiano, traductor del herbario al latín, desde un territorio identificado como "esta India" y para cuenta de las "hierbas medicinales de los indios". El herbario nos presenta un amplio repertorio de medicinas para aliviar los males que aquejan al ser humano distinguiendo, cuando corresponde, a hombres y mujeres, niños, ancianos y gobernantes organizados en trece capítulos que recorren el cuerpo, comenzando con la cabeza y concluyendo con "algunas señales de la cercanía de la muerte". El formato general propone el nombre en náhuatl de una o más plantas seguida de una ilustración, un subtítulo con el nombre de una enfermedad en latín que se desea remediar y luego el o los remedios propuestos, acompañados de otras indicaciones terapéuticas.

Las 180 ilustraciones que contiene el herbario dan cuenta de que estas buscaban particularizar las formas y colores de las plantas representadas desplegando unas imágenes que no se relacionan con la condición esquemática atribuida a los herbarios medievales, pese a la similitud formal que posee el Libellus con el Herbarius latinus impreso en Mainz por Peter Schöffer en 1484 (en North, 2015) y que, eventualmente, sirviera como modelo para la elaboración del manuscrito (Figura 6). ${ }^{9}$ Además, no hay huellas sobre quiénes realizaron estas ilustraciones pero las prácticas de registro y escritura nahua permiten suponer que fueron elaboradas por uno o más especialistas del dibujo. Visto que las plantas se representan vivas, como si recién hubieran sido abstraídas de su entorno, existe una opción estética que pasa por "darle vida" a la planta que se dibuja, cuestión que informa acerca de las convenciones representacionales que comparten los artífices, más allá de las variaciones mencionadas en el apartado anterior. En esa línea, no son "naturalistas" pues no recogen "lo que se ve", del 
mismo modo que no hay intención de dar cuenta de los tamaños diferenciados. Al mismo tiempo, la disposición de las ilustraciones varía enormemente: hay fojas que poseen dos hileras de ilustraciones, inferior y superior, y donde sólo se han escrito los nombres de las plantas sin otra explicación (Figura 7) o, también, una variación entre la cantidad de hierbas que son ilustradas en relación con el recetario escrito.

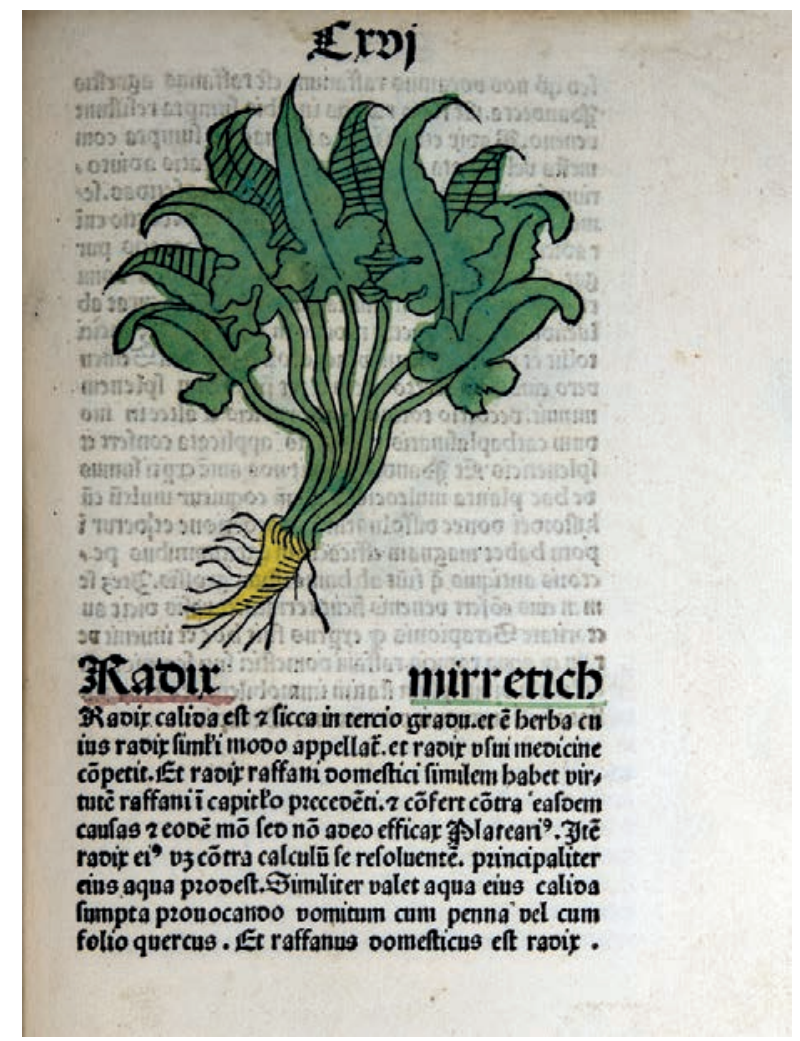

Figura 6. Herbarius Latinus, f. 37. (Schöffer [1484], en North, 2015).

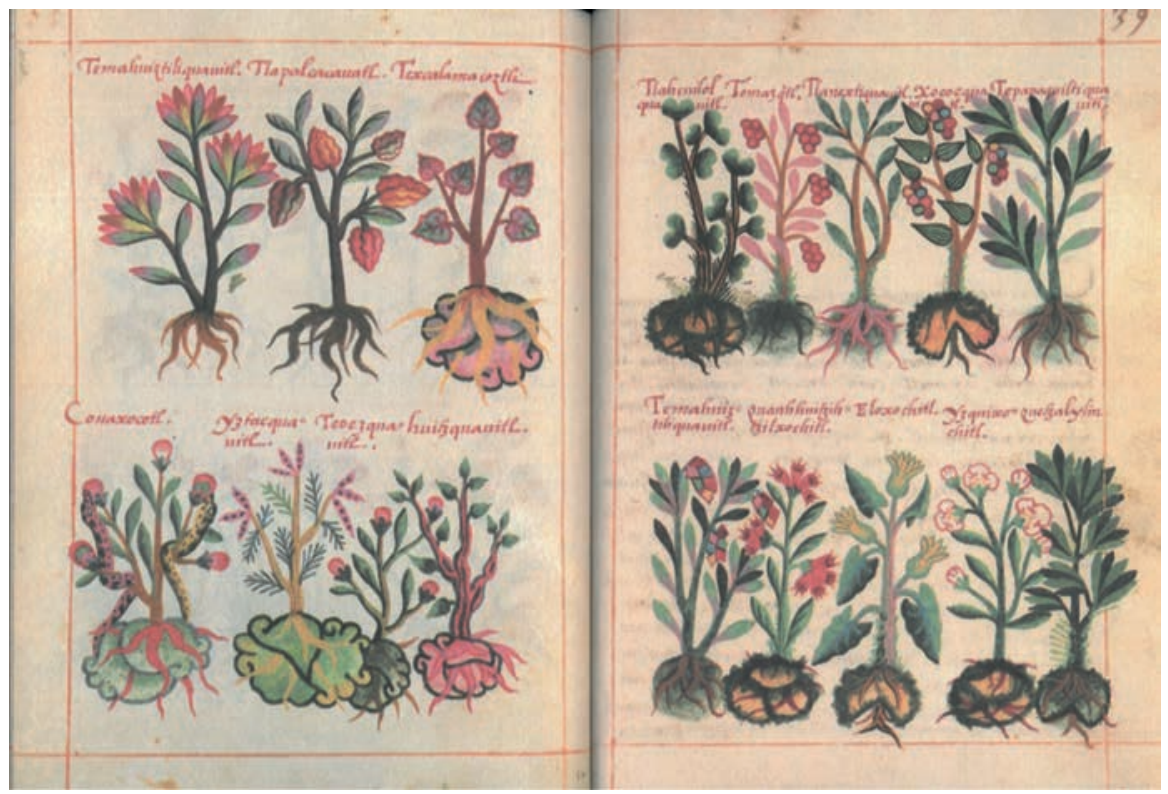

Figura 7. Libellus de medicinalibus indorum herbis, fs 38v. y 39r. (Del Pozo, 1996). 
10. Magaloni identifica al menos veintidós pintores nativos en la creación del Códice, "expertos de la antigua tradición de consignar el conocimiento mediante pinturas -en náhuatl se les Ilamaba tlacuilolli -, a la vez que conocían muy bien la iconografía y el estilo pictórico del Renacimiento europeo" (Magaloni, 2014: 2).
11. Esto también corre para la propia composición de la representación escrita de la información. Al igual que en otros casos, Sahagún se tomó la libertad de poner un texto vago con el nombre de "Relación digna de ser contada", ensayo sobre los problemas de la educación en México en el siglo XVI. Véase Martínez (1980: LXI-LXII).
Estos elementos dan cuenta de las múltiples formas de representación inscritos en estos artefactos compuestos $\mathrm{y}$, al mismo tiempo, evidencian otra cuestión de suma relevancia: la heterogeneidad de estructuras dentro del campo de lo visible y lo legible en las formas de expresión de indígenas coloniales. $\mathrm{Si}$ se considera la propuesta de Mitchell (2009) sobre la necesidad de superar el análisis de los lenguajes visuales y escritos desde la lógica de la comparación, se puede entender que las disonancias formales dan cuenta de un tipo de relación entre estas formas de comunicar que no se agota en la subordinación de la imagen al orden de la escritura alfabética. En ese sentido, la pregunta no sería "¿Cuál es la diferencia (o similitud) entre palabras e imágenes?”, [sino] “¿Qué efecto tienen estas diferencias (o similitudes)?" Es decir: ¿por qué es importante la forma en que las palabras y las imágenes se yuxtaponen, se mezclan o se separan?" (Mitchell, 2009: 85-86).

Esta disrupción en la composición se halla también patente en La historia general de las cosas de Nueva España de Sahagún (1577). A diferencia del Libellus, las hierbas representadas en el manuscrito integran un orden mayor del conocimiento que se guía por el modelo de las enciclopedias medievales y, por supuesto, el modelo de la historia natural. Así nos hace saber la organización del conocimiento náhuatl que Sahagún emplea para destinar, junto a los animales y los minerales, al igual que arbustos, árboles y frutos del territorio, el repertorio de hierbas clasificadas como medicinales. Se entiende que, en la composición de este manuscrito final, Sahagún "decidió que sus pintores ${ }^{10}$ hicieran sus ilustraciones después y no antes que los escribanos" (Martínez, 1981: XCII), concentrándose en las dos columnas, náhuatl y español. El espacio dejado en medio de los capítulos o al final de cada párrafo evidencia que el manuscrito buscaba subordinar las imágenes a la exigencia del texto escrito, poniendo en juego la capacidad de adaptación de las representaciones visuales de los manuscritos previos por parte de los jóvenes artífices o la capacidad de captar el entorno natural, aunque, como es notorio, la subordinación no fue hegemónica.

La adecuación de esta formulación queda patente a la hora de apreciar las ilustraciones. La sección de "hierbas medicinales" se compone de 142 descripciones de hierbas, generalmente ilustradas dentro de un cuadro, otras con más de una dentro de la representación, otras incorporadas al costado de los escritos y otras siendo partícipes de acciones curativas de manera similar a las ilustraciones que acompañan la sección sobre las enfermedades del cuerpo humano y de las medicinas contra ellas del libro décimo. Como ya mencioné, la tendencia general de representar a las hierbas con un paisaje de fondo hace del Códice Florentino un manuscrito que porta elementos estéticos propios de los formatos renacentistas, principalmente la noción de perspectiva (Magaloni, 2014) y la vocación paisajística (Zetina et al. 2011: 226). La variedad de formas no es sólo expresión de las estrategias de acomodo de la ilustración al texto sino también de la diversidad de artífices que participan en su fabricación. Esta heterogeneidad llega a tal punto que, al igual que en otras secciones del manuscrito, ya sea por decisiones deliberadas de Sahagún o por motivos desconocidos, las ilustraciones copan el espacio de la traducción al español del relato en náhuatl (Figura 2), borrando la equivalencia compositiva de las historias naturales y que tendían a destinar un equilibrio entre el texto sobre una hierba y su respectiva ilustración. ${ }^{11}$ 


\section{Disputas por la definición de la materia medicinal}

La lectura de las representaciones cala más hondo cuando se presta atención a otros manuscritos cuya elaboración responde a objetivos distintos, como es el caso del Códice Magliabecchiano (De Loubat, 1804). Su impronta religiosa, plasmada en las 92 páginas, da cuenta de una especie de glosario religioso y cosmológico donde, junto a los 20 días del tonalpohualli, se mencionan deidades y ritos vinculados con las creencias mexicanas. Llama la atención el modo en que se presenta el "demonio" llamado "mayabel q quiere decir maguei por quel çumo que delsalia esta borrachera y baila[n]" (f. 57v.) (Figura 8). Efectivamente, esta deidad se representa junto a una planta de maguey de manera bastante similar al modo en que nos expresa el Códice florentino.

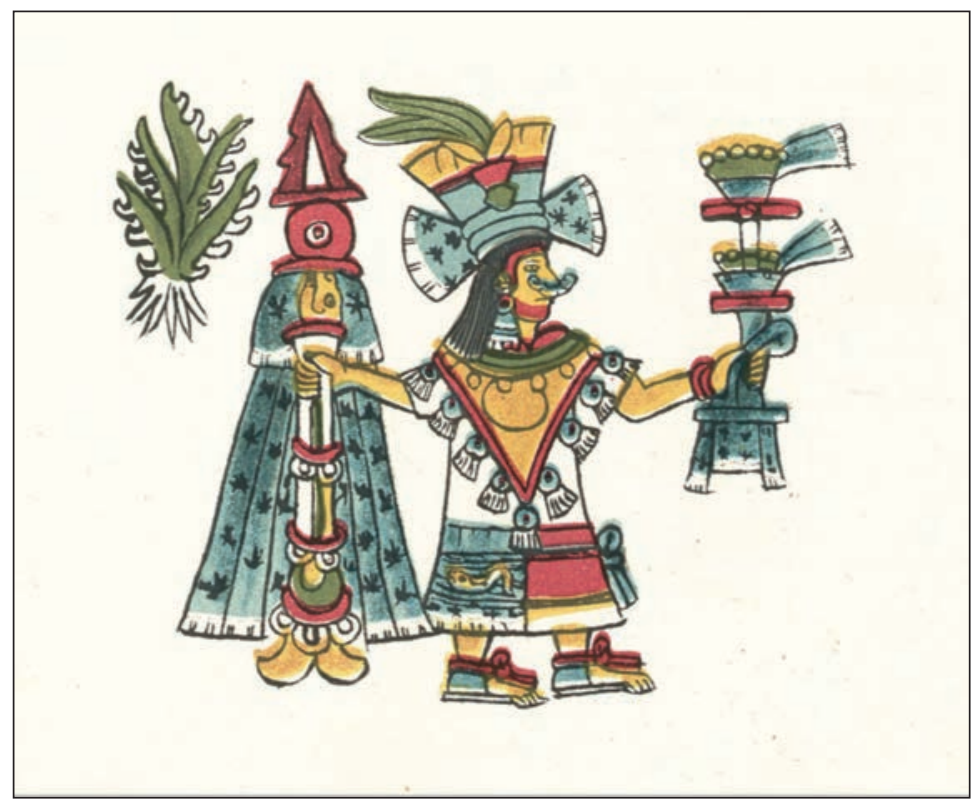

Figura 8. Códice Magliabecchiano, f. 58r. (De Loubat, 1804).

Tal similitud visual abre un campo de interrogantes. La representación del Códice Magliabecchiano (De Loubat, 1804) que se comenta al reverso de la foja previa nos habla de prácticas idolátricas que involucran, como es el caso, la participación de hierbas, plantas, raíces u otras sustancias naturales. Eso no debiera sorprender a nadie. Como es bien sabido, la condena al uso de ciertas hierbas ha sido, y sigue siendo, una constante en las disputas por el control de las prácticas curativas, que puede detectarse en los casos de idolatría y hechicería condenados por el arzobispo Zumárraga en la década de $1530^{12} \mathrm{o}$ en los comentarios de los primeros impresos médicos del siglo XVI, como los 12. Véase, AGN México (1912). del cirujano Alonso López de Hinojosos ([1578] 1595), fray Agustín Farfán ([1579] 1610), y Juan de Cárdenas ([1591] 1988). Los casos más emblemáticos los constituyen las sustancias alucinógenas, aunque también todo tipo de hierbas o plantas que participen en ritos o prácticas sospechosas para el orden cristiano.

Un ejemplo de esta actitud es el comentario del cirujano Alonso López de Hinojosos sobre la epidemia de cocoliztle de 1576 y su vinculación con el humo del tabaco (piciete). En la segunda edición de su obra, Summa y Recopilación de Cirugía ([1578] 1595), nos cuenta que tras la autopsia realizada sobre un cadáver en Guaxaca en 1592, de quien "le dixeron que era gran chupador de humo de piciete", vio "que estaua su cuerpo como los que auia hecho anatomía; diez 
(27.1 (2019)

(a)

y seis años antes; cuando el gran cocoliste" (López de Hinojosos, [1578] 1595: fs.150v.-151r.). Se trataba de un cuerpo pestilente producto del humo "chupado", efecto de la astucia del demonio que "haziendole creer que mejor de sus enfermedades, y los engaña, porque siempre se andan ahogando, y amarillos" (López de Hinojosos, [1578] 1595: f. 151r.). O también la ambivalencia con la que Juan de Cárdenas en su Problemas y secretos maravillosos de las Indias ([1591] 1988) se aproxima a las virtudes medicinales del piciete, expresado de esta manera:

cuando me pongo a imaginar quién aya sido el inventor de chupar este humo del piciete [...] sospecho que algún ángel le aconsejo a los indios o algún demonio; que sea ángel está puesto en razón, porque él nos libra de tantas enfermedades que verdaderamente parece medicina de ángeles; y que parezca ser remedio del demonio también lo está, porque si nos ponemos a mirar al que lo está chupando, lo veremos echar por la boca y narizes bocanadas de hidiondo humo, que parece un volcán o boca de infierno" (Cárdenas, [1591] 1988: 195-196).

En ambos casos el problema de fondo no pareciera ser el piciete en sí mismo sino el modo en que este es consumido. En ese sentido, la discusión entre los médicos era importante porque exigió "repensar lo que debía considerarse medicamento y lo que no" (Morales Sarabia, 2014: 70), definiendo los contornos de la "matera médica" del territorio novohispano. En cuanto entidad material, no hay que olvidar que lo que se define al momento de discutir lo medicinal son los bienes de consumo que pasan a formar parte del repertorio medicinal de occidente y que, por consecuencia, debe acoplarse a los criterios ideológicos del vivir en policía que son propios de la urbe cristiana (Bauer, 2002).

Considero que el juicio que tilda de idolátrico el uso de las hierbas y plantas por parte de los indios mexicanos tiene que ver con las disputas en torno a los regímenes de valor (Appadurai, 1991) que instala la experiencia colonial y se proyecta hasta nuestros días. Las escrituras del saber médico, dentro de las cuales se inscriben los herbarios y las historias naturales, participan de la valoración de la naturaleza del territorio a través de filtros que depuran las hierbas a través de clasificaciones que distinguen lo "medicinal" de lo "idolátrico". De esa tarea es ejemplar el ejercicio clasificatorio de Sahagún, quien trata al maguey en distintas secciones de su obra, siendo medicinal solo el uso de corteza de pulque y su mezcla con otras hierbas medicinales como el chichicpatli (1577: f. 169v.). Es para la sección del libro sobre idolatrías en las que puede visualizarse nuevamente al maguey; esta vez, en función

13. Opera Medicinalia del doctor Francisco Bravo fue el primer libro de medicina escrito en parte, o totalmente, en Nueva España e impreso en 1570. Es un trabajo extenso y escrito en latín, inscrito en la tradición escolástica y que, entre otros secciones, dedica un apartado a las virtudes de la zarzaparilla impugnando algunas opiniones del célebre divulgador Nicolás Monardes, quien en 1545 imprimió en Sevilla su obra titulada “Dos libros, el uno que trata de todas las cosas que se traen de nuestras Indias Occidentales, que sirven al uso de la medicina, y el otro que trata de la piedra bezoar, y de la yerva escuerçonera", reimpreso en dos ocasiones (1565 y 1596) y editado con una segunda parte en 1571 (Trabulse, 1992: 44-45). de sus usos demoniacos, como los que describió Toribio de Benavente sobre las fiestas que se hacían en Tlaxcala. El fraile nos cuenta que tras el ayuno, a media noche todos se bañaban y se "sacrificaban muy a menudo las orejas con aquellas puntas del maguey, y siempre les daban algunas de ellas para que tuviesen..." (Toribio de Benavente, [1858] 2014: 66).

Por consiguiente, se puede interpretar que las representaciones visuales de las hierbas se entroncan con una riña de mayor envergadura que involucra, entre otras prácticas, las formas de representación y el vínculo que puedan establecer con el mundo de prácticas que les otorgan sentido dentro del tejido social. ¿No es esa, acaso, la utilidad de los grabados de la zarzaparrilla dentro de la Opera Medicinalia de Francisco Bravo (1570) (Figura 9), primer impreso médico novohispano y prueba para decir bajo los criterios galénicos propios del saber médico que es una raíz "cálida y seca" y contrarrestar, de esa manera, el criterio clasificatorio de Nicolás Monardes? ${ }^{13}$ Junto a la escritura en latín, la 
imagen grabada se hace partícipe de los modos en que el conocimiento sobre la naturaleza del Nuevo Mundo comenzaba a ser difundido en los circuitos de transmisión del saber europeo, construyendo un discurso científico desde la circulación de conocimientos en una escala global (Cañizarez-Esguerra 2006) y articulando los sistemas de representación de manera conjunta: el texto cuenta y la imagen lo apoya como soporte secundario.

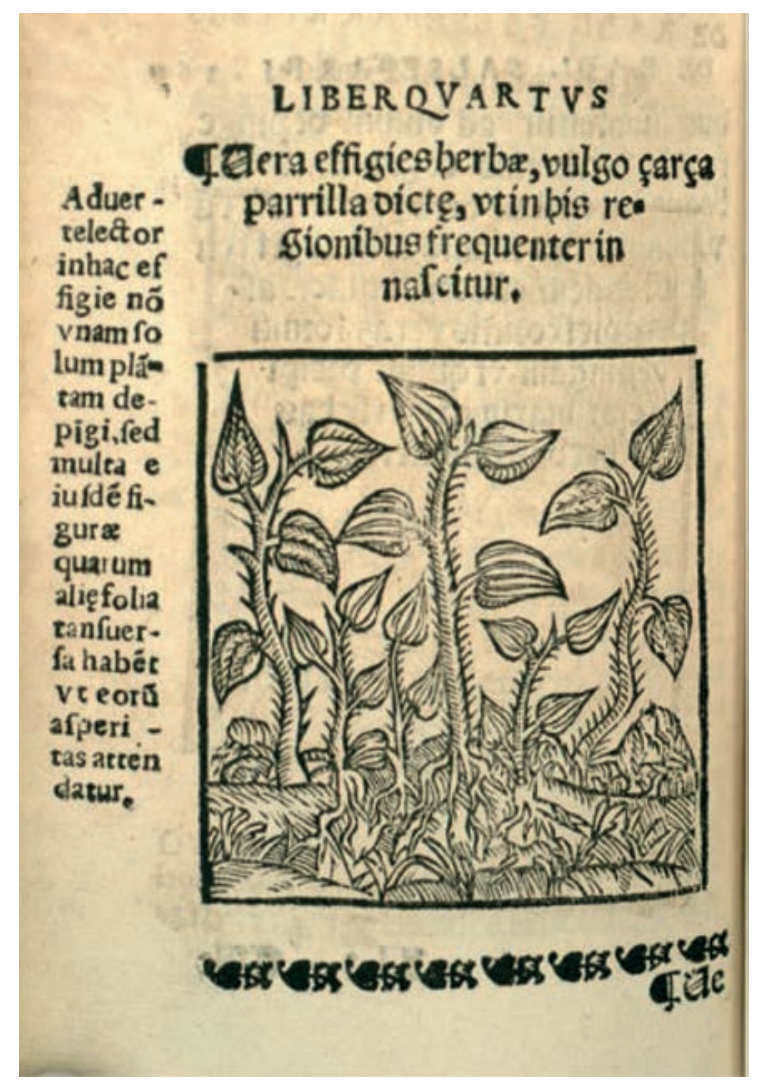

Figura 9. Opera Medicinalia, f. 573r. (Bravo, 1570).

Las digresiones y fisuras respecto de estos esfuerzos que presentan los manuscritos, junto con las irregularidades de la composición mencionada y la presencia de formas de representación de hierbas y plantas en otros soportes, habilita pensar la condición autónoma de la imagen que construyen los indios coloniales sobre su naturaleza y sus propios saberes. Al no responder al escrito que busca constituir a la ilustración como evidencia del conocimiento natural, el tipo de solución visual corre de manera dispar. Las imágenes buscaban ser un medio para hacer "visible antes los ojos del rey" las hierbas del territorio, cuestión que los indios supieron desarrollar desde estrategias plásticas heterogéneas y situadas dentro de las prácticas de enunciación que experimentan y condensan los cambios de la conquista y la tutela evangelizadora. En esa medida, ¿qué clase de naturaleza es la que manifiestan estas representaciones? La ausencia dentro del escrito de los ritos y otras formas de dar significado a las hierbas medicinales permitió plantear a Bernand y Gruzinski que los indios silenciaron, de manera consciente o inconsciente, los conocimientos indígenas, y los disfrazaron dentro de las estrategias de representación visual que les enseñaron los propios franciscanos. Tal fue el punto que "los pintores indígenas se las ingeniaron para alterar escenas de género características de los tacuina Sanitatis de la Europa Medieval o para amañar informaciones de 
14. En ese sentido, resulta relevante el concepto de ixiptlah, que quiere decir "imagen, sustituto de algo o alguien" (Magaloni, 2014: 10) y que opera tanto para objetos como para personas que resultan los representantes o sustitutos de alguien, incuso de un dios. Según López Austin, la clave está en el concepto "xip", que deriva de "desollar, levantar la piel", la que a su vez se asocia a la noción de nahualli, que define la capacidad de una persona poderosa para transformarse en otro ser y adoptar su identidad. Magaloni comenta, además, el planteamiento de Salvador Reyes Equiguas, para quien los ixiptlah eran siempre producto de la creación humana. Para él, "ixtli" es "rostro", "ojo", lo que en síntesis podría ser entendido como una elaboración que oscila entre "representación" y "presencia con un punto de vista propio" y que sería aplicable a las imágenes del Códice florentino" (Magaloni, 2014: 12). naturaleza idolátrica con una presentación de apariencia anecdótica o pintoresca" (Bernand y Gruzinski, 2005: 311).

\section{Conclusión}

Los géneros discursivos y visuales que participan en el ejercicio de la clasificación, jerarquización y representación de la "materia médica" del territorio americano son empleados desde el lugar de la producción "in situ". Como he mencionado, son elaboraciones en y desde el territorio americano cuyo diálogo con la tradición europea genera "la descentralización de los saberes, la inversión de los puntos de vista, la auto interrogación de la tradición europea" (Gruzinski, 2010: 207). Sin ir más lejos, Diana Magaloni (2014) sugiere que el significado simbólico de los pigmentos utilizados en las ilustraciones del Códice Florentino daría cuenta de que lo que los artífices indígenas plasmaron en las páginas del manuscrito no son sólo imágenes en términos occidentales sino también "sujetos", entidades tan vivientes como los animales y los humanos. ${ }^{14}$ Más allá de la factibilidad de este proyecto, rescato el énfasis de Magaloni en la idea de que toda imagen es una operación simbólica y cognitiva que dialoga con otro tipo de conceptualizaciones de la cultura. En ese sentido, más allá de optar por una posición más o menos optimista respecto a la continuidad de los lenguajes, escrituras y soportes prehispánicos, me parece más importante darle cabida al heterogéneo campo de soluciones que pueden encarnar estos artefactos culturales dentro de la semiosis colonial.

La pregunta sobre qué elemento es más o menos prehispánico es inoperante, tal como nos hacen saber las imágenes del Herbario De la Cruz-Badiano y el Códice florentino con las "rarezas" visuales que nos presentan. Estos artefactos fueron producidos por actores inscritos en instancias particulares, indios alfabetizados y vinculados al Colegio de Santa Cruz de Tlatelolco, de los cuales sabemos poco o casi nada. Solo las huellas inscritas en estos registros permiten pensar en que la participación siempre es mucho más amplia y diversa de lo que los textos nos dicen. No obstante, estos pequeños indicios motivan a ahondar de manera más sistemática en el lenguaje visual desarrollado en y desde la condición colonial, donde el mantenimiento de ciertos criterios o la invención de formas de representaciones nos hablan de cómo los indios, por citar a Klor de Alva (1922), se apropiaron de lo europeo y articularon su propia narrativa sobre la naturaleza medicinal del territorio. No obstante, hay que reconocer que pese a la sintonía del programa educativo y la educación visual que experimentaron estos indios, los manuscritos portan particularidades únicas y resuelven de manera distinta las interacciones entre recursos y tradiciones diferentes (Russo, 2005).

De todas formas, esto no anula la posibilidad de pensar en un horizonte compartido entre sujetos que, ante la exigencia colonial, fueron partícipes de la elaboración de artefactos desde sus propias maneras de otorgar sentido a la ilustración de las hierbas, en tensión con los sistemas de representación de la naturaleza, el espacio e incluso las nociones temporales. Así, ¿puede leerse la "esfera" que acompaña las raíces del herbario como una manera de negar la tridimensionalidad de la representación occidental?, ¿no es acaso un dibujo hecho en perspectiva desde abajo, como si se estuviera bajo tierra? (Figura 10). Sea como sea, este tipo de interrogantes invitan a ahondar de manera más sistemática en la representación visual de las hierbas medicinales en contextos coloniales y evaluar, como invitaba Mitchell, (2009) la particularidad textual provocada o reprimida por el diálogo entre sistemas de comunicación 
en constante tensión. En definitiva, abordar desde la exigencia colonial soluciones negociadas en contextos tremendamente heterogéneos.

\section{Agradecimientos}

Este escrito es producto de las reflexiones e interrogantes desarrolladas en el curso de posgrado "Para una reflexión de lo colonial desde los colonizados: el caso andino en los siglos XVI y XVII" del magíster en Estudios Latinoamericanos de la Universidad de Chile, a cargo del profesor José Luis Martínez, durante el primer semestre de 2018. Agradezco al Profesor la posibilidad de ahondar en temáticas geográficas y culturales ajenas a los propósitos del curso y también por animarme a publicar los resultados de estas reflexiones.

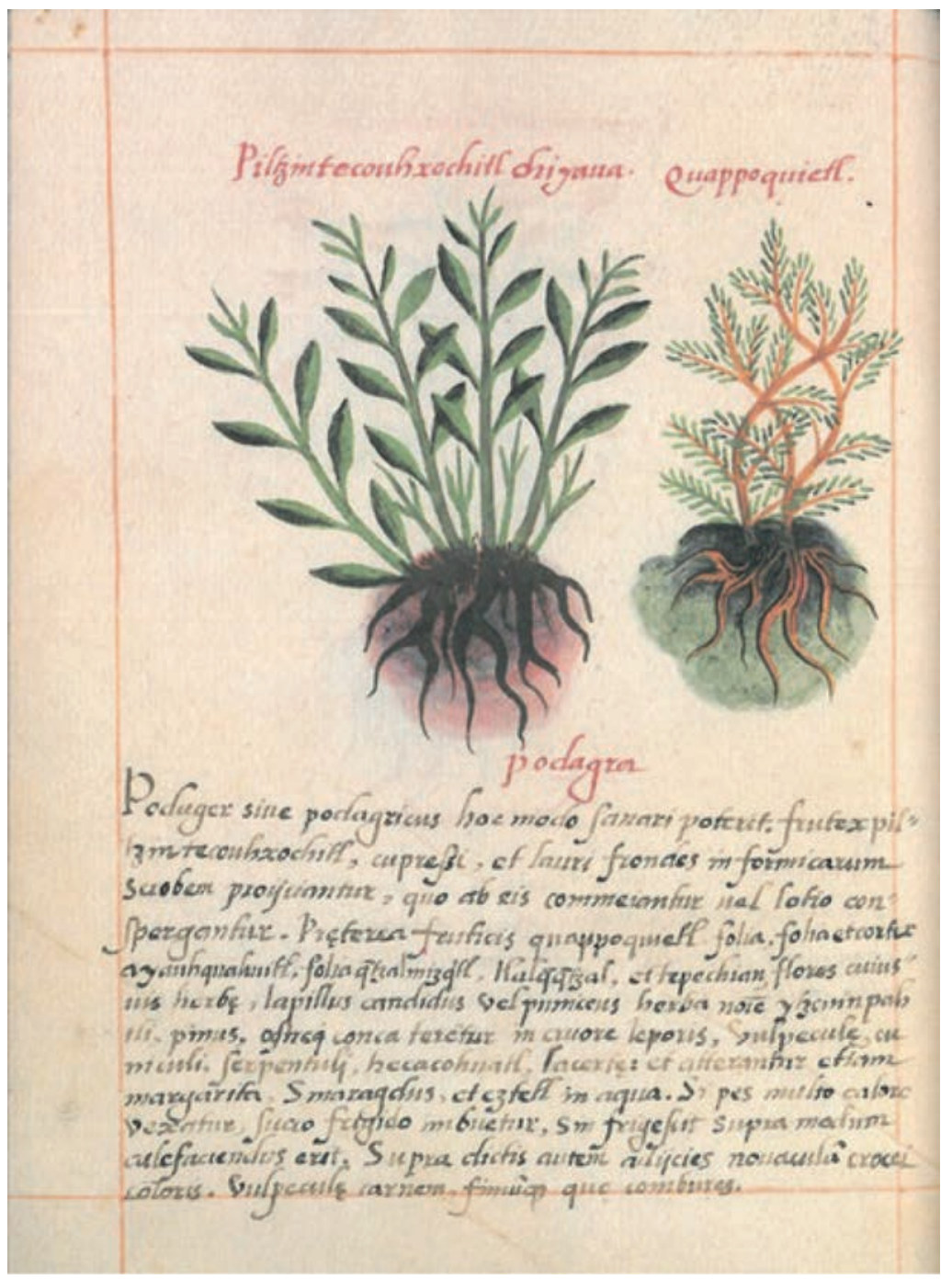

Figura 10. Libellus de medicinalibus indorum herbis, f. 35v. (Del Pozo, 1996). 


\section{Fuentes documentales}

》Archivo General de la Nación (AGN), México (1912). Procesos De Indios Idolatras y Hechiceros. México, Tip. Guerrero Hnos.

"Benavente "Motolinía”, Fray T. ([1858] 2014). Historia de los indios de la Nueva España, edición, estudio y notas de Mercedes Serna Arnaiz y Bernat Castany Prado. Madrid, Real Academia Española - Centro para la Edición de los Clásicos Españoles.

» Bravo, F. (1570). Opera Medicinalia, in quibus quam plurima extant scitu medico necessaria. México, Pedro Ocharte. Lafragua Digital. Disponible en internet:http://www.lafragua. buap.mx:818o/dig/browse/book_cover.jsp?id=libro_antiguo\&key=book_4e1355. xml\&num=o. Consultado el 30 de junio de 2018.

»Cortés, H. ([1526] 1993). “Merced y mejora de Hernán Cortés a los caciques de Axapusco y Tepeyahualco" en Martínez, J. L. (ed.), Documentos Cortesianos I 1518-1528. Secciones I a III: 6o-76. México, Universidad Nacional Autónoma de México - Fondo de Cultura Económica.

"Cárdenas, J. De ([1591] 1988). Problemas y secretos maravillosos de las Indias. México, Alianza Editorial.

»De la Cruz, M. ([1552] 1996). Libellus De Medicinalibus Indorum Herbis. Manuscrito Azteca De 1552. Según traducción latina de Juan Badiano. México, Fondo de Cultura Económica, Instituto Mexicano Del Seguro Social.

»De Loubat, D. (1804). Codez Magliabecchiano XIII. 3. Manuscrit Mexicain Post-Colombien. Roma, Bibliothèque Nationale de Florence.

» Farfán, A. ([1579] 1610). Tratado Breve De Medicina. México, Imprenta de Geronymo Balli, por Cornelio Cesar.

"López de Hinojosos, A. ([1578] 1595). Summa y Recopilación De Cirvgia, Con Vn Arte Para Sangrar, y examen de barberos. México, Impreso por Pedro Balli.

" Monardes, N. (1574). Primera y segunda y tercera parte de la Historia medicinal de las cosas que se traen de nuestras Indias Occidentales que sirven en medicina. Sevilla, Impreso en casa de Alonso Escrivano. Disponible en internet:https://books.google.cl/books?id $=p E H e Q N i T z A o C \& p g=P A 6 \& h l=e s \&$ source=gbs_toc_r\&cad=3\#v=onepage\&q\&f=false. Consultado el 30 de junio de 2018.

" North, M. (2015). Medieval Herbals In Movable Type. Circulating Now From the Historical Collections of the National Library of Medicine. Maryland, National Library of Medicine. Disponible en internet: https://circulatingnow.nlm.nih.gov/2015/07/og/medievalherbals-in-movable-type/. Consultado el 30 de junio del 2018.

»Sahagún, B. D. (1577). Historial general de las cosas de Nueva España: el Códice Florentino. World Digital Library. Disponible en Internet: https://www.wdl.org/en/item/10og6/ view/1/1/. Consultado el 30 de junio de 2018.

"Stresser-Péan, G. (1995). El Códice De Xicotepec. Estudio e interpretación. México, Gobierno del Estado de Puebla, Centro Francés de Estudios Mexicanos y Centroamericanos - Fondo de Cultura Económica. 


\section{Q Bibliografía}

" Afanador Llanch, M. J. (2011). Nombrar y representar: escritura y naturaleza en el Códice de la Cruz-Badiano, 1552. Fronteras de la Historia 16: 13-41.

"Anderson, F. J. (1997). An Ilustrated History of the Herbals. Nueva York, Columbia University Press.

» Appadurai, A. (1991). “Introducción: las mercancías y la política del valor” en Appadurai, A. (Ed.), La Vida Social De Las Cosas. Perspectivas culturales de la mercancía: 17-88. México, Grijalbo.

» Bauer, A. (2002). Somos lo que compramos. Historia de la cultura material en América Latina. México, Taurus.

» Bernand, C. y S. Gruzinski (2005). Historia del Nuevo Mundo. Tomo II. Los mestizajes, 15501640. México, Fondo de Cultura Económica.

"Bleichmar, D. (2015). The imperial visual archive: images, evidence, and knowledge in the early modern Hispanic world. Colonial Latin American Review 24: 236-266.

»Cañizarez-Esguerra, J. (2006). Nature, Empire, And Nation. Stanford, Stanford University Press.

"Cummins, T. (2004). Brindis con el Inca. La abstracción andina y las imágenes coloniales de los queros. Lima, Universidad Nacional Mayor de San Marcos - Universidad Mayor de San Andrés - Embajada de los Estados Unidos de América.

"Del Pozo, E. C. (1996). “Valor médico y documental del manuscrito" en De la Cruz, M. Libellus De Medicinalibus Indorum Herbis. Manuscrito Azteca De 1552. Según traducción latina de Juan Badiano: 329-348. México, Fondo de Cultura Económica - Instituto Mexicano Del Seguro Social.

"Descola, Ph. (2001). "Construyendo naturalezas. Ecología simbólica y práctica social” en Descola, Ph. y G. Pálsson (coords.), Naturaleza y sociedad. Perspectivas antropológicas: 101-123. México, Siglo XXI.

" Duverger, Ch. (1996). La conversión de los indios de Nueva España. Con el texto de los Coloquios de los Doce de Bernandino de Sahagún (1564). México, Fondo de Cultura Económica.

"Elliott, B. (2011). The World of the Renaissance herbal. Renaissance Studies 24: 24-41.

» Foucault, M. ([1969] 2008). La arqueología del saber. Buenos Aires, Siglo XXI.

》 Foucault, M. ([1973] 1987). El orden del discurso. Barcelona, Tusquets.

" Gruzinski, S. (2010). Las cuatro partes del mundo. Historia de una mundialización. México, Fondo de Cultura Económica.

» Gruzinski, S. (2013). La colonización de lo imaginario. Sociedades indígenas y occidentalización en el México español. Siglos XVI-XVIII. México, Fondo de Cultura Económica.

" Klor de Alva, J. J. (1992). "El discurso nahua y la apropiación de lo europeo" en León Portilla, M.; Gutiérrez Estévez, M., H. Gossen, G. y J. J. Klor de Alva (eds.), De Palabra y Obra En El Nuevo Mundo 1. Imágenes interétnicas: 339-368. Madrid, Siglo XXI.

"Laird, A. (2014). Nahuas and Caesars: Classical Learning and Bilingualism in PostConquest Mexico: An Inventory of Latin writings by Authors of the Native Nobility. Classical Philology 109: 150-169. 
» Lamana, G. (2016). Dominación Sin Dominio. El Encuentro Inca-español En El Perú Colonia Temprano. Perú, IFEA - Centro Bartolomé de las Casas.

»León Portilla, M. (2003). Literaturas Indígenas De México. México, Fondo de Cultura Económica - MAPFRE.

»León Portilla, M. (2012). La riqueza semántica de los códices mesoamericanos. Estudios De Cultura Náhuatl 42: 139-160.

" López Austin, A. (2012). Cuerpo Humano E Ideología. Las concepciones de los antiguos nahuas. México, Universidad Nacional Autónoma de México - Instituto De Investigaciones Antropológicas.

" Magaloni Kerpel, D. (2014). Los Colores Del Nuevo Mundo. Artistas, materiales y la creación del Códice Florentino. México, Universidad Nacional Autónoma de México - The Getty Research Institute.

»Martínez, J. L. (1981). "Prólogo” en Sahagún, B. D. El México Antiguo: IX- ClI. Venezuela, Ed. Ayacucho.

" Martínez, J. L. (2009). Registros andinos al margen de la escritura: el arte rupestre colonial. Boletín del Museo Chileno de Arte Precolombino 14: 9-25.

" Mignolo, W. (1992). “La semiosis colonial: la dialéctica entre representaciones fracturadas y hermenéuticas pluritópicas" en González Stephan, B. y L. H. Costigan (eds.), Crítica y descolonización: el sujeto en la cultura latinoamericana: 27-47. Caracas, Universidad Simón Bolivar - The Ohio State University.

" Mignolo, W. (1994). The Darker Side of Renaissance. Ann Harbor, Michigan University Press.

» Mitchell, W. J. T. (2009). Teoría de la imagen. Madrid, Akal.

"Morales Sarabia, A. (2014). “Tres caminos posibles: una ausencia, una marca tipográfica y un evento fortuito. El peyote y otras hierbas en la Materia Médica (Siglos XVI-XVII)" en Pardo-Tomás, J. y M. Sánchez Menchero (eds.), Geografías Médicas. Orillas y Fronteras Culturales De La Medicina (Siglos XVI Y XVII): 47-74. México, Universidad Nacional Autónoma de México, Centro de Investigaciones Interdisciplinarias en Ciencias y Humanidades.

" O’ Gorman, E. ([1958] 2004). La invención de América. Investigación acerca de la estructura histórica del nuevo mundo y del sentido de su devenir. México, Fondo de Cultura Económica.

» Ortiz de Montellano, B. (1993). Medicina, Salud y Nutrición Aztecas. México, Siglo XXI.

"Pardo-Tomás, J. (2016). "Making Natural History in New Spain, 1525-1590”. Wendt, H. (ed.), The Globalization of Knowledge in the Iberian Colonial World: 29-51. Alemania, Max Planck Research Library for the History and Development of Knowledge, Proceedings 8.

» Real Academia Española. (2014) Diccionario de la lengua española. $23^{\underline{a}}$ edición. Madrid, España.

》 Rama, Á. (2004). La ciudad letrada. Santiago, Tajamar Editores.

" Rey Bueno, M. (2004). Junta de herbolarios y tertulias espagíricas: el círculo cortesano de Diego de Cortavila (1597-1657). DYNAMIS 24: 243-267.

》 Reyes Equiguas, S. (2016). "El scriptorium del Colegio de la Santa Cruz de Tlatelolco a través de los códices Florentino y De la Cruz-Badiano” en Hernández, E. y P. Máynez (eds.), El Colegio de Tlatelolco. Síntesis de historias, lenguas y culturas: 26-38. México, Editorial Grupo Destiempos.

》Russo, A. (2005). El Realismo Circular. Tierras, Espacios y Paisajes De La Cartografía Indígena Novohispana. Siglos XVI y XVII. México, Universidad Autónoma de México, Instituto de Investigaciones Estéticas. 
» Todorov. T. (1987). La Conquista de América. El problema del otro. Buenos Aires, Siglo XXI.

» Turner, G. (2007). El Códice de la Cruz-Badiano y su extensa familia herbaria. Historias 68: 109-122.

» Trabulse. E. (1992). Historia De La Ciencia En México. Estudios y textos. Siglo XVI. México, Conacyt - Fondo de Cultura Económica.

» Verón, E. (1993). La semiosis social. Fragmentos de una teoría de la discursividad. Barcelona, Gedisa.

»Viesca Triviño, C. (1995). “El Códice De la Cruz-Badiano, primer ejemplo de una medicina mestiza” en Fresquet, J. L. y J. M. López Piñero (eds.), El mestizaje cultural y la medicina novohispana del siglo XVI: 71-9o. Valencia, Universitat de València - CSIC.

» Zetina, S., Falcón, T. Arroyo, E., y J. L. Ruvalcaba (2011). “The Encoded Languaje of Herbs: Material Insights into the De la Cruz-Badiano Codex” en Wolf, G. y J. Connors (eds.), Colors Between Two Worlds. The Florentine Codex Of Bernardino De Sahagún: 221256. Italia, Kunsthistorisches Institut in Florenz, Max-Planck Institut -Villa I Tatti, The Hardvard University Center for Italian Renaissance Studies. 